\title{
THE COMPARATIVE KEEPING QUALITIES OF PALM KERNEL, COCONUT, GROUND-NUT AND OTHER OIL-CAKES.
}

\author{
BY WILLIAM GODDEN: \\ (Department of Agriculture, the University, Leeds.)
}

ONE of the difficulties which hinder the extended use of the nutoil-cakes (palm kernel, coconut and ground-nut) is the prevalent impression that these cakes deteriorate rapidly on keeping. In recent articles dealing with these cakes frequent reference has been made to this point. Thus Voelcker(9) in his Annual Report for 1914 states that "one inconvenience attaching to palm-nut and coconut cakes is that they do not keep as well as linseed and cotton cakes and that there is a tendency for them to turn rancid." In his Report for 1915, however, he says, "I have come across but few instances either with palm-nut cake or meal, in which these have been rancid or not in good condition." Murray (8) states that manufacturers should realise that they still have to reassure farmers regarding the keeping qualities of palm kernel cake. In a later article in the Journal of the Board of Agriculture (3) it is stated that "palm-nut kernel cakes in the past have had the reputation of soon going rancid....At the present day, before the kernels are crushed they are subjected to a process of cooking, by which the ferment that causes the oil to turn rancid is rendered inactive." The validity of this latter assertion seems doubtful in the light of the recent work of Calder (2) which shows that the lipase, present in the resting seed in the form of its zymogen, is not destroyed during the manufacture of the cake, the mass of crushed kernels not being sufficiently heated in every part prior to pressing to secure this object completely. Similar statements have been made as to the liability of coconut and ground-nut cakes to become rancid on storing $(3,4)$.

Journ, of Agric. Sci. vIII 
In view of these facts and of the endeavours which are being made to increase the use of these cakes in this country, it was thought advisable to re-examine the whole subject of the keeping qualities of these cakes and to compare them, in this respect, with other cakes, which are already widely used by British farmers. The three nut-cakes were therefore compared with linseed, undecorticated cottonseed, "soycot" and soya cakes, the cakes being kept.

(a) under ordinary farm conditions in the cake store at The Manor Farm, Garforth;

(b) in the laboratory under conditions most likely to promote decomposition.

Of each particular kind of cake four adjacent cakes from the middle of a press were obtained fresh from the crushers. Of these four cakes, two were stored at Garforth in the cake store, stacked in the usual way alongside the cakes then being fed on the farm, whilst, of the other two, one was used for the laboratory trials and the other kept in reserve. When the cakes were sampled for analysis, strips about eight inches wide were taken from the middle of each cake, ground up, mixed separately and sampled by quartering in the usual way.

In addition to careful observation of the appearance, physical condition and other external characteristics of the cakes, the following points were examined:

(1) The changes in the composition of the cake with respect to $(a)$ crude protein, $(b)$ true protein, $(c)$ oil, due allowance being made for the variation in the moisture content of the cake during storage.

(2) The increase in the amount of the free fatty acids in the oil during storage.

(3) The part played by the oil in any changes undergone by the nitrogenous constituents of the cake.

\section{FARM TESTS.}

The two cakes of each kind were put into the cake store on March 28th, 1916, the first cake being sampled on June 15th, and the second on September 13th, 1916, by the method described above. The samples were thus obtained, roughly after three and six months storage respectively. The six months storage covered the whole of the summer months, the cakes thus being kept at temperatures very suitable for the activity of micro-organisms. The percentage composition of the dry matter of the cakes at each stage is given in Table I. 
At the end of the six months there was no sign of mould on any of the cakes nor was any unpleasant smell noticeable. The coconut cake had become quite soft and could be crumbled in the hand and was, therefore, difficult to handle. In view of the difficulty which Mackenzie and Powell (6) experienced in getting cattle to clean up coconut cake; even when it was mixed with cottonseed and linseed cakes, unless the coconut cake was in moderately big pieces, this softening would be an apparent objection to the lengthy storage of this cake. The palm kernel cake could be broken with moderate ease, whilst all the other cakes were still quite hard.

TABLE I. Cakes stored at the farm.

\begin{tabular}{|c|c|c|c|c|c|c|}
\hline \multirow{2}{*}{\multicolumn{2}{|c|}{ Kind of cake }} & \multirow[b]{2}{*}{$\begin{array}{l}\text { Length of } \\
\text { time stored }\end{array}$} & \multicolumn{4}{|c|}{ Percentages calculated on the dry matter } \\
\hline & & & \multirow{2}{*}{$\begin{array}{c}\text { Crude } \\
\text { protein } \\
\% \\
32.78\end{array}$} & \multirow{2}{*}{$\begin{array}{c}\text { True } \\
\text { protein } \\
\% \\
28.77\end{array}$} & \multirow{2}{*}{$\begin{array}{c}\text { Oil } \\
\% \\
13 \cdot 43\end{array}$} & \multirow{2}{*}{$\begin{array}{c}\text { Free fatty acids } \\
\text { as } \% \text { of oleic } \\
\text { acid in the oil } \\
\% \\
11 \cdot 23\end{array}$} \\
\hline & & ( Nil & & & & \\
\hline \multirow[t]{3}{*}{ Linseed } & \multirow[t]{3}{*}{... } & $\{3$ months & $31 \cdot 19$ & $28 \cdot 07$ & $13 \cdot 46$ & $18 \cdot 07$ \\
\hline & & 6 months & $32 \cdot 35$ & $28 \cdot 01$ & 14.02 & $29 \cdot 82$ \\
\hline & & ( Nil & 34.08 & $31 \cdot 21$ & $11 \cdot 27$ & $14 \cdot 65$ \\
\hline \multirow{3}{*}{\multicolumn{2}{|c|}{ Ground-nut }} & $\{$ months & 31.98 & $28 \cdot 19$ & $10 \cdot 72$ & $37 \cdot 65$ \\
\hline & & 6 months & $32 \cdot 99$ & $27 \cdot 92$ & $10 \cdot 25$ & $56 \cdot 02$ \\
\hline & & (Nil & $20 \cdot 68$ & 19.92 & $15 \cdot 59$ & 5.84 \\
\hline \multirow[t]{2}{*}{ Coconut } & \multirow[t]{2}{*}{$\ldots$} & $\left\{\begin{array}{l}3 \text { months } \\
6 \text { months }\end{array}\right.$ & $\begin{array}{l}20 \cdot 29 \\
21 \cdot 21\end{array}$ & $\begin{array}{l}19 \cdot 4.2 \\
19 \cdot 95\end{array}$ & $\begin{array}{l}14.46 \\
12.55\end{array}$ & $\begin{array}{l}45 \cdot 39 \\
73 \cdot 45\end{array}$ \\
\hline & & Nil & $19 \cdot 49$ & $18 \cdot 88$ & $10 \cdot 38$ & $5 \cdot 70$ \\
\hline \multirow{2}{*}{\multicolumn{2}{|c|}{ Palm kernel }} & 3 months & $19 \cdot 00$ & $18 \cdot 51$ & $10 \cdot 68$ & $25 \cdot 34$ \\
\hline & & 6 months & $19 \cdot 02$ & $19 \cdot 01$ & $10 \cdot 76$ & $40 \cdot 93$ \\
\hline \multirow{4}{*}{\multicolumn{2}{|c|}{$\begin{array}{l}\text { Undecorticated } \\
\text { cottonseed }\end{array}$}} & (Nil & 25.55 & 23.69 & $5 \cdot 33$ & $61 \cdot 48$ \\
\hline & & $\{3$ months & $25 \cdot 03$ & $22 \cdot 93$ & $5 \cdot 77$ & $82 \cdot 85$ \\
\hline & & 6 months & $24 \cdot 99$ & $23 \cdot 85$ & $5 \cdot 47$ & $87 \cdot 44$ \\
\hline & & (Nil & $34 \cdot 66$ & $33 \cdot 87$ & 6.01 & $20 \cdot 95$ \\
\hline \multirow[t]{3}{*}{ "Soycot" } & \multirow[t]{3}{*}{$\cdots$} & $\{3$ months & $36 \cdot 01$ & $32 \cdot 91$ & 6.04 & $37 \cdot 42$ \\
\hline & & ( 6 months & $36 \cdot 07$ & $33 \cdot 44$ & $5 \cdot 85$ & $65 \cdot 33$ \\
\hline & & $\mathrm{Nil}$ & $47 \cdot 94$ & $46 \cdot 35$ & $6 \cdot 61$ & $5 \cdot 18$ \\
\hline \multirow[t]{2}{*}{ Soya } & \multirow[t]{2}{*}{$\ldots$} & $\{3$ months & $48 \cdot 75$ & $46 \cdot 79$ & 6.90 & $8 \cdot 80$ \\
\hline & & 6 months & $48 \cdot 41$ & 46.52 & $7 \cdot 22$ & $16 \cdot 37$ \\
\hline
\end{tabular}

It will be seen that, with the possible exception of coconut cake, the cakes show no change in the percentage composition of their dry matter, beyond the limits of error due to sampling and the possible slight variation between the cakes as manufactured, during the six months storage. The one noticeable change, common to all the cakes, though in varying degree, is the increase in the amount of free fatty acids present in the extracted oil. In this connection the most striking 
feature is the high initial acidity in the case of the cottonseed cake, due to the fact, subsequently ascertained, that the cottonseed cakes used were made from a not very satisfactory sample of cottonseed from the notoriously bad crop of 1915 . This explanation is borne out by the following data obtained from a number of samples of cottonseed cake examined very soon after their manufacture.

\section{TABLE II. Acidity of fresh Collonseed Cake.}

\begin{tabular}{|c|c|c|c|c|c|c|}
\hline \multirow[b]{2}{*}{ Kind } & \multirow{2}{*}{$\begin{array}{l}\text { Year of } \\
\text { crop }\end{array}$} & \multirow{2}{*}{$\begin{array}{c}\text { No. of } \\
\text { samples }\end{array}$} & \multirow{2}{*}{$\begin{array}{c}\text { Oil } \\
\text { (average) } \\
\%\end{array}$} & \multicolumn{3}{|c|}{$\begin{array}{l}\text { Free fatty acids } \\
\text { expressed as \% of } \\
\text { oleic acid in the oil }\end{array}$} \\
\hline & & & & Max. & Min. & Average \\
\hline Egyptian ... & 1915 & 14 & $4 \cdot 72$ & 80.67 * & $11 \cdot 44$ & $34 \cdot 71$ \\
\hline Egyptian ... & 1916 & 6 & $4 \cdot 76$ & $22 \cdot 33$ & S.57 & $12 \cdot 71$ \\
\hline Bombay & 1915 & 2 & $4 \cdot 79$ & $12 \cdot 11$ & $7 \cdot 46$ & $9 \cdot 78$ \\
\hline S. American & 1915 & 1 & $3 \cdot 80$ & - & - & $13 \cdot 84$ \\
\hline Soudanese ... & 1915 & 1 & $4 \cdot 27$ & - & - & $7 \cdot 32$ \\
\hline
\end{tabular}

* Described by the crushers as made from the oldest seed of a very poor crop.

The final acidities, as shown in Table I, are all high, even the soya cake, which is the lowest, having an acidity more than three times the initial value. Leaving out of consideration the abnormal case of cottonseed cake the highest final acidity is shown by the coconut cake, which also shows the greatest relative increase, the lowest relative increase being given by linseed cake. If this final free acidity be taken as a measure of the keeping qualities of the cakes then, after soya and linseed cakes, palm kernel cake is the most satisfactory. These results would indicate that the presence of a fat-splitting enzyme is common to all the oil-cakes and cannot be adduced as a specific disadvantage of palm kernel cake.

It is difficult to say just what practical significance should be attributed to this increase in acidity. The presence of appreciable quantities of free fatty acids in a feeding-stuff is commonly regarded as undesirable but, provided the acidity be not so high as to cause actual derangement of the digestive functions, it is at least doubtful whether the nutritive value of the oil is seriously lowered by this liberation of the fatty acids present in it. Such direct evidence as is available points at least to this conclusion. Thus in experiments carried out by Munk(7) equally good results were obtained whether mixed fatty acids were fed as such or in the form of their glycerides, the results indicating that the animal body is capable of building up neutral fat from these free acids and depositing them in the body. 


\section{LABORATORY TESTS.}

For the purpose of the laboratory experiments a strip from the middle of each cake was used. This was ground as finely as possible, a sample drawn for immediate analysis, and then lots of 200 grams of each cake taken and incubated under the following conditions:

Exp. 1. The ground cake was placed in a wide-mouthed bottle, $8 \%$ of water was mixed in with it, the bottle loosely corked, and the whole incubated at $37^{\circ}$ for twenty-six days.

Exp. 2. Similar to Exp. 1. The cakes were weighed before and after incubation.

Exp. 3. In addition to the $8 \%$ of water, 5 c.c. of toluene were added to each cake in order to prevent mould formation.

It will be noted that, in each case, the cakes were kept in a confined space, in moist condition and at a relatively high temperature, conditions which may be regarded as likely to ensure a severe test of keeping properties.

During the periods of incubation in experiments (1) and (2) the first cake to show mould was the "soycot," which was distinctly mouldy at the end of two days. This was closely followed by cottonseed, ground-nut and soya cakes in the order named. At the end of four days the palm kernel and coconut cakes, though showing no signs of mould formation, had an ethereal and at the same time a somewhat cheesy smell. At the end of the period of incubation the four firstnamed cakes were mouldy throughout the whole mass, the "soycot" and soya cakes having a smell resembling that of fish meal. The linseed cake showed a development of mould at one spot but, apart from a slightly mouldy smell, no other change was apparent. Neither the palm kernel nor coconut cakes showed any sign of mould formation, but the cheesy smell was intensified in the case of the former. During the incubation in the presence of toluene (Exp. 3) there was no development of mould on any of the cakes, nor was there any noticeable change in appearance or smell.

As in the case of the cakes stored at the farm, the oil extracted after incubation shows a much higher free fatty acid content than before, the rise in most cases being of the same order as that found in the farm tests. The one exception is the soya cake where the rise is much greater as a result of incubation in the moist state than from storing at the farm, this difference being due probably to the fat-splitting action of the moulds formed on the cake during incubation. In contrast with 
the results obtained in the farm tests a marked decrease in the percentage of oil in the dry matter was found with all the cakes, except coconut cake. There is a marked rise in the percentage of "crude protein" in the dry matter of the "soycot" and soya cakes and to a lesser extent in the cottonseed and ground-nut cakes. During incubation in the presence of toluene (Exp. 3) there is no apparent change

TABLE III. Incubation of Moist Cakes at $37^{\circ}$.

\begin{tabular}{|c|c|c|c|c|c|c|}
\hline & & & Percen & yes cal & 20 & the dry matter \\
\hline Kind of cake & & $\begin{array}{l}\text { Before or after } \\
\text { incubation }\end{array}$ & $\begin{array}{l}\text { Crude } \\
\text { protein }\end{array}$ & $\begin{array}{c}\text { True } \\
\text { protein }\end{array}$ & Öil & $\begin{array}{l}\text { Free fatty acids } \\
\text { as } \% \text { of oleic } \\
\text { acid in the oil }\end{array}$ \\
\hline & & (Before & $\begin{array}{c}\% \\
32 \cdot 78\end{array}$ & $\begin{array}{c}\% \\
28 \cdot 77\end{array}$ & $\begin{array}{c}\% \\
13 \cdot 43\end{array}$ & $\begin{array}{c}\% \\
11 \cdot 23\end{array}$ \\
\hline & & After (1) & $33 \cdot 11$ & $30 \cdot 59$ & $9 \cdot 33$ & 56.90 \\
\hline Linseed & $\cdots$ & After (2) & $32 \cdot 83$ & $28 \cdot 88$ & $11 \cdot 18$ & $70 \cdot 50$ \\
\hline & & After (3) & 32.53 & $28 \cdot 30$ & $13 \cdot 40$ & $36 \cdot 50$ \\
\hline & & (Before & 34.08 & $31 \cdot 21$ & $11 \cdot 27$ & $14 \cdot 65$ \\
\hline & & After (1) & $37 \cdot 35$ & $34 \cdot 85$ & $4 \cdot 27$ & $71 \cdot 40$ \\
\hline Ground-nut & & After (2) & $35 \cdot 95$ & $34 \cdot 23$ & $3 \cdot 93$ & $68 \cdot 60$ \\
\hline & & After (3) & $32 \cdot 44$ & $31 \cdot 06$ & $10 \cdot 84$ & $62 \cdot 50$ \\
\hline & & (Before & $20 \cdot 68$ & 19.92 & $15 \cdot 59$ & $5 \cdot 84$ \\
\hline & & After (1) & $21 \cdot 25$ & $19 \cdot 78$ & $14 \cdot 72$ & $64 \cdot 10$ \\
\hline Coconut & $\cdots$ & After (2) & $20 \cdot 89$ & $19 \cdot 55$ & $15 \cdot 84$ & $61 \cdot 20$ \\
\hline & & After (3) & $20 \cdot 37$ & $20 \cdot 08$ & $15 \cdot 65$ & $75 \cdot 40$ \\
\hline & & (Before & $19 \cdot 49$ & $18 \cdot 88$ & $10 \cdot 38$ & $5 \cdot 70$ \\
\hline Palm kernel & & After (I) & $20 \cdot 13$ & $19 \cdot 51$ & $2 \cdot 95$ & 58.90 \\
\hline 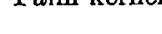 & & After (2) & 19.54 & $19 \cdot 22$ & $4 \cdot 44$ & $64 \cdot 30$ \\
\hline & & After (3) & $19 \cdot 19$ & $18 \cdot 87$ & $9 \cdot 99$ & $65 \cdot 70$ \\
\hline & & (Before & $25 \cdot 55$ & $23 \cdot 69$ & $5 \cdot 33$ & $61 \cdot 48$ \\
\hline Undecortica & ated & After (I) & $27 \cdot 59$ & $25 \cdot 95$ & 1.07 & $68 \cdot 70$ \\
\hline cottonsee & & After (2) & $28 \cdot 16$ & $25 \cdot 89$ & 0.58 & $71 \cdot 40$ \\
\hline & & After (3) & $25 \cdot 00$ & $23 \cdot 58$ & $5 \cdot 15$ & $93 \cdot 80$ \\
\hline & & (Before & $34 \cdot 66$ & $33 \cdot 87$ & 6.01 & 20.95 \\
\hline "Soycot" & & After (1) & $43 \cdot 54$ & $40 \cdot 68$ & 0.65 & 54.90 \\
\hline & $\cdots$ & After (2) & $43 \cdot 73$ & $40 \cdot 35$ & 0.60 & $57 \cdot 90$ \\
\hline & & After (3) & $34 \cdot 44$ & $33 \cdot 23$ & $5 \cdot 94$ & $65 \cdot 80$ \\
\hline & & (Before & $47 \cdot 94$ & $46 \cdot 35$ & $6 \cdot 61$ & $5 \cdot 18$ \\
\hline & & After (1) & $55 \cdot 44$ & $52 \cdot 78$ & $4 \cdot 75$ & $56 \cdot 10$ \\
\hline Soya & $\cdots$ & After (2) & $55 \cdot 96$ & $55 \cdot 14$ & $1 \cdot 54$ & $64 \cdot 00$ \\
\hline & & After (3) & $47 \cdot 75$ & $46 \cdot 40$ & $6 \cdot 70$ & $9 \cdot 29$ \\
\hline
\end{tabular}

The figures in brackets in the second column indicate the conditions of incubation as set out above.

in the percentage composition of the dry matter of any of the cakes examined. There is in all cases a rise in the free fatty acid content of the oil, due to the lipases present in the cakes. A clearer idea of the real significance of the changes in composition indicated can be obtained by comparing the absolute weights of each ingredient of the dry matter 
present before and after incubation. For the samples used in experiments (2) and (3) it was possible, from the data obtained, to calculate these absolute weights and they are given in Table IV.

TABLE IV. Incubation of Moist Cakes at $37^{\circ}$.

\begin{tabular}{|c|c|c|c|c|c|c|}
\hline \multirow{2}{*}{\multicolumn{2}{|c|}{ Kind of cake }} & $\begin{array}{l}\text { Before or after } \\
\text { incubation }\end{array}$ & $\begin{array}{l}\text { Total dry } \\
\text { matter } \\
\text { grams }\end{array}$ & $\begin{array}{c}\text { Crude } \\
\text { protein } \\
\text { grams }\end{array}$ & $\begin{array}{l}\text { True } \\
\text { protein } \\
\text { grams }\end{array}$ & $\underset{\text { grams }}{\text { Oil }}$ \\
\hline & & (Before & $177 \cdot 64$ & $58 \cdot 2$ & $51 \cdot 1$ & $23 \cdot 9$ \\
\hline \multirow[t]{3}{*}{ Linseed } & $\ldots$ & After (2) & 176.09 & $57 \cdot 8$ & $50 \cdot 8$ & $19 \cdot 7$ \\
\hline & & After (3) & $178 \cdot 48$ & $58 \cdot 1$ & 50.5 & $23 \cdot 9$ \\
\hline & & (Before & $182 \cdot 2$ & $62 \cdot 1$ & $56 \cdot 9$ & $20 \cdot 5$ \\
\hline \multirow{3}{*}{\multicolumn{2}{|c|}{ Ground-nut }} & $\{$ After (2) & $171 \cdot 1$ & $61 \cdot 6$ & $58 \cdot 1$ & $6 \cdot 7$ \\
\hline & & (After (3) & 187.5 & $61 \cdot 6$ & $57 \cdot 6$ & $20 \cdot 3$ \\
\hline & & Before & $179 \cdot 4$ & $37 \cdot 1$ & $35 \cdot 7$ & $27 \cdot 9$ \\
\hline \multirow[t]{3}{*}{ Coconut } & $\cdots$ & $\{$ After (2) & $176 \cdot 5$ & $36 \cdot 7$ & $34 \cdot 4$ & $27 \cdot 8$ \\
\hline & & After (3) & $179 \cdot 6$ & $36 \cdot 6$ & $36 \cdot 0$ & $28 \cdot 1$ \\
\hline & & Before & $178 \cdot 9$ & $34 \cdot 9$ & $33 \cdot 8$ & $18 \cdot 6$ \\
\hline \multirow{2}{*}{\multicolumn{2}{|c|}{ Palm kernel }} & After (2) & $175 \cdot 0$ & $34 \cdot 2$ & $33 \cdot 7$ & $7 \cdot 8$ \\
\hline & & After (3) & 180.9 & $34 \cdot 7$ & $34 \cdot 1$ & $18 \cdot 1$ \\
\hline \multirow{4}{*}{\multicolumn{2}{|c|}{$\begin{array}{l}\text { Undecorticated } \\
\text { cottonseed }\end{array}$}} & Before & $176 \cdot 1$ & $45 \cdot 0$ & $41 \cdot 7$ & $9 \cdot 4$ \\
\hline & & $\{$ After (2) & $156 \cdot 7$ & $44 \cdot 1$ & $40 \cdot 6$ & 0.9 \\
\hline & & After (3) & $177 \cdot 7$ & $44 \cdot 4$ & $41 \cdot 9$ & $9 \cdot 2$ \\
\hline & & Before & 176.0 & $61 \cdot 0$ & $59 \cdot 6$ & $10 \cdot 6$ \\
\hline \multirow[t]{3}{*}{ "Soycot" } & $\cdots$ & After (2) & $151 \cdot 0$ & $66 \cdot 0$ & $60 \cdot 9$ & 0.9 \\
\hline & & After (3) & $180 \cdot 1$ & $62 \cdot 0$ & $59 \cdot 8$ & $10 \cdot 7$ \\
\hline & & Before & $175 \cdot 0$ & $83 \cdot 9$ & $81 \cdot 1$ & $11 \cdot 6$ \\
\hline \multirow[t]{2}{*}{ Soyn } & $\ldots$ & After (2) & $154 \cdot 1$ & $86 \cdot 2$ & $84 \cdot 9$ & $2 \cdot 4$ \\
\hline & & (After (3) & $177 \cdot 1$ & $84 \cdot 5$ & $82 \cdot 2$ & 11.8 \\
\hline
\end{tabular}

It will be seen from these figures that, during the incubation in the presence of toluene (Exp. 3) there was no loss of dry matter, crude protein or oil in any case. Under the conditions of experiment (2) an increase in weight of crude protein is shown by the "soycot" cake to the extent of 5 grams on 61 grams and by the soya cake of about half that amount. The results for these two cakes are quite abnormal in this respect as compared with the other cakes examined. On this account, further samples of cottonseed, "soycot" and soya cakes were obtained from the crushers and 100 gram lots were incubated under the conditions set out in Table V.

In this series there was no development of mould on any of the cakes until the moisture content at the commencement of the incubation exceeded $13 \%$, that is in the sets where the moisture content was made up to $18 \%$ and $21 \%$ respectively. The moulds which developed on the various cakes were examined by Miss K. Sampson, B.Sc. and in all cases species of Aspergillus were found, of which the following were 
identified, viz.:-A. candidus, $A$. herbariorum, and $A$. niger. In addition Mucor racemosus and Rhizopus nigricans were found on the "soycot" and cottonseed cakes.

TABLE V. Incubation of Cakes with varying Moisture Content.

\begin{tabular}{|c|c|c|c|c|c|c|c|}
\hline & & \multirow{2}{*}{\multicolumn{2}{|c|}{$\begin{array}{c}\text { Before } \\
\text { incubation } \\
\text { grams }\end{array}$}} & \multicolumn{4}{|c|}{$\begin{array}{l}\text { After incubation } \\
\text { Moisture content at the start }\end{array}$} \\
\hline & & & & $\begin{array}{l}\text { As per } \\
\text { sample } \\
\text { grams }\end{array}$ & $\begin{array}{l}\text { Made to } \\
13 \% \\
\text { grams }\end{array}$ & $\begin{array}{l}\text { Made to } \\
18 \% \\
\text { grams }\end{array}$ & $\begin{array}{l}\text { Made to } \\
21 \% \\
\text { grams }\end{array}$ \\
\hline \multicolumn{8}{|c|}{ Undecort. Cottonseed Cake. } \\
\hline Total dry matter & $\cdots$ & $\cdots$ & $89 \cdot 01$ & $88 \cdot 24$ & $88 \cdot 32$ & 84.99 & $75 \cdot 55$ \\
\hline Oil .... & ... & ... & $4 \cdot 97$ & $5 \cdot 10$ & $4 \cdot 80$ & $2 \cdot 51$ & $0 \cdot 42$ \\
\hline Crude protein & ... & ... & $22 \cdot 56$ & $22 \cdot 79$ & $22 \cdot 25$ & $22 \cdot 62$ & $21 \cdot 24$ \\
\hline Crude fibre... & $\cdots$ & ... & $23 \cdot 10$ & $22 \cdot 37$ & $22 \cdot 39$ & $22 \cdot 39$ & $25 \cdot 37$ \\
\hline Sol. carbohydrates & & ... & $33 \cdot 18$ & $32 \cdot 92$ & $33 \cdot 10$ & $32 \cdot 46$ & $23 \cdot 50$ \\
\hline $\begin{array}{l}\text { Free fatty acids } \\
\text { oleic acid in oil . }\end{array}$ & $\begin{array}{l}\text { as } \% \\
\ldots\end{array}$ & $\begin{array}{l}\text { of } \\
\cdots\end{array}$ & $31 \cdot 75$ & $71 \cdot 09$ & $81 \cdot 53$ & $75 \cdot 76$ & $50 \cdot 62$ \\
\hline \multicolumn{8}{|c|}{ "Soycot" Cake. } \\
\hline Total dry matter & $\cdots$ & ... & $87 \cdot 19$ & $87 \cdot 13$ & $86 \cdot 86$ & $85 \cdot 19$ & $80 \cdot 17$ \\
\hline Oil $\ldots$ & ... & $\ldots$ & $4 \cdot 95$ & $4 \cdot 86$ & 4.91 & $3 \cdot 50$ & $2 \cdot 44$ \\
\hline Crude protein & $\ldots$ & $\ldots$ & $30 \cdot 37$ & $30 \cdot 40$ & $29 \cdot 95$ & $30 \cdot 46$ & $29 \cdot 91$ \\
\hline Crude fibre... & $\ldots$ & $\ldots$ & $12 \cdot 45$ & $12 \cdot 52$ & $12 \cdot 55$ & $12 \cdot 83$ & $14 \cdot 24$ \\
\hline Sol. carbohydrates & & $\ldots$ & 33.61 & $33 \cdot 40$ & $33 \cdot 52$ & $32 \cdot 44$ & $27 \cdot 74$ \\
\hline $\begin{array}{l}\text { Free fatty acids } \\
\text { oleic acid in oil. }\end{array}$ & $\begin{array}{l}\text { as } \% \\
\ldots\end{array}$ & $\begin{array}{l}\text { of } \\
\cdots\end{array}$ & $9 \cdot 04$ & $17 \cdot 50$ & $19 \cdot 26$ & $48 \cdot 59$ & $49 \cdot 92$ \\
\hline \multicolumn{8}{|c|}{ Soya Cake. } \\
\hline Total dry matter & $\ldots$ & $\ldots$ & $89 \cdot 72$ & $89 \cdot 00$ & $89 \cdot 23$ & $77 \cdot 78$ & $80 \cdot 68$ \\
\hline Oil ... & $\ldots$ & $\ldots$ & $5 \cdot 57$ & $5 \cdot 62$ & $5 \cdot 26$ & $1 \cdot 15$ & $2 \cdot 21$ \\
\hline Crude protein & ... & $\ldots$ & $42 \cdot 75$ & $41 \cdot 84$ & $42 \cdot 49$ & $41 \cdot 87$ & $42 \cdot 97$ \\
\hline Crude fibre... & $\cdots$ & $\cdots$ & $5 \cdot 46$ & $5 \cdot 76$ & $5 \cdot 56$ & $5 \cdot 76$ & $5 \cdot 93$ \\
\hline Sol. carbohydrates & & $\ldots$ & $30 \cdot 58$ & $30 \cdot 44$ & $30 \cdot 60$ & $23 \cdot 94$ & $24 \cdot 33$ \\
\hline $\begin{array}{l}\text { Free fatty acids } \\
\text { oleic acid in oil }\end{array}$ & $\begin{array}{l}\text { as } \% \\
\ldots\end{array}$ & of & $7 \cdot 86$ & $14 \cdot 03$ & $14 \cdot 06$ & $47 \cdot 94$ & $34 \cdot 75$ \\
\hline
\end{tabular}

The foregoing results obtained with these fresh cakes and the examination of further samples of similar cakes did not confirm the previous results as to the increase in the crude protein content of "soycot" and soya cakes during incubation, and it must be concluded, therefore, that the increases shown in the first case are due to some peculiarity in the particular samples of cake used.

From an examination of the behaviour of cottonseed meal on in- ubation with varying water content, König(5) and Bremer(1) have shown that mould formation first occurred with a water content of $.14 \%$, the moulds predominating until the water content exceeded $30 \%$, when the bacteria obtained the upper hand, the mould flora 
changing with varying water content. They further found that the mould formation was always accompanied by a loss of organic matter, which in the first stages of moulding fell upon the oil fraction, but with a higher water content and the appearance of Penicillium glaucum, the $\mathrm{N}$-free extractives were largely consumed. The results given in Tables IV and V are in full accord with these statements. In the first series (Table IV) a marked loss in dry matter only occurred where there was a development of moulds, namely in the case of the cottonseed, "soycot," soya and ground-nut cakes. In the second series (Table V) a loss in dry matter is shown only by the two sets of cakes, where the moisture content had been brought up to $18 \%$ and $21 \%$ respectively, and it was only on these sets that there was any mould formation. This loss in dry matter was divided between the oil and the soluble carbohydrates, falling largely on the oil fraction where the moisture content was only $18 \%$.

In order to determine the part played by the oil in the changes which the cakes undergo during incubation, portions of the ground cakes were extracted with light petroleum to remove the oil, the residues being dried in a steam oven and then freely exposed to the air for several hours. Portions of 50 grams of each extracted cake were then incubated for three weeks at $37^{\circ} \mathrm{C}, 8 \%$ of water being added to the cakes, which had already taken up from $6-10 \%$ of moisture from the air.

TABLE VI. Cakes extracted with Light Petroleum.

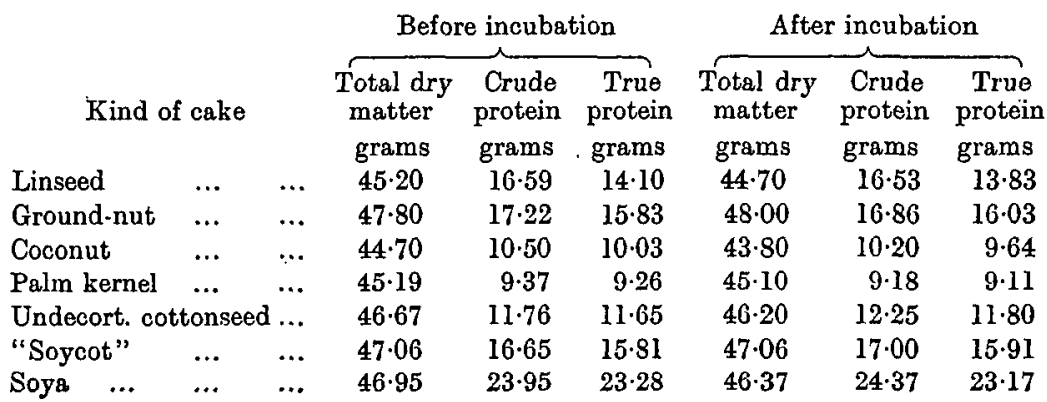

In no case was there any development of mould on the cake or any change in smell noticeable at the end of three weeks, although the cakes had been freely exposed to the air and were incubated under conditions suitable for their re-infection, owing to the presence in the incubator of other samples of cake covered with mould. As will be seen from Table VI there was no change in total dry matter or protein during the incubation. The presence of oil appears, therefore, to be one of the 
conditions favouring the development of moulds on oil-cakes, and the consequent loss of organic matter.

\section{Conclusions.}

1. So far as keeping properties are concerned, palm kernel cake compares favourably with most of the oil-cakes commonly used on the farm.

2. The only change which occurs during storage under ordinary farm conditions is one which is common to all the oil-cakes examined, viz. an increase in the free fatty-acid content of the oil.

3. During incubation at $37^{\circ}$, in a moist state, on only four of the cakes examined, namely cottonseed, ground-nut, "soycot" and soya cakes, was there any marked development of moulds.

4. This development of moulds is always accompanied by loss of organic matter, the loss being distributed between the oil and the soluble carbohydrates of the cake.

5. Moulds did not develop, during incubation, on cakes from which the oil had been previously extracted.

6. To prevent moulding of cakes and the consequent loss of organic matter, dry storage is essential. Where cakes are stored under very damp conditions serious reduction in their oil-content may take place.

In conclusion I have to thank Professor Crowther for his helpful advice during the progress of the work, and I wish also to thank the Olympia Oil Co., Ltd., Selby; the various branches of the British Oil and Cake Mills, Ltd.; and Messrs John Curtis and Co., Ltd., Bristol, for kindly supplying me with the various cakes, used in this enquiry.

\section{LITERATURE.}

(1) Bremer, W." Chem. Centralblatt, 1903, 1, 890.

(2) CALDER, R. B., Journ. of Agric. Sc., 1916, 7, 470-472.

(3) Journ. of Board Agric., 1915, 21, 1029.

(4) Journ. of Board Agric., 1915, 22, 308-313.

(5) KöNIG, J., Fühlings Landw. Zeit., 1902, 77.

(6) Mackenzie, K. J. J. and Powell, E. H., Journ. of Board Agric., 1916, 23 $117-123$.

(7) Monk, J., Arch.f. Anat. u. Physiol., 1879, 371.

- Virch. Arch., 80, 10.

- Nalurforscher, 1883, 25, 239.

(8) Morray, J. AlaN, Journ. of Board Agric., 1914, 21, 700.

(9) Voetcker, J. A., Journ. R. Agric. Soc., 1914, 75, 271; 1915, 76, 302. 